\title{
Disorder of sex development-intellectual disability syndrome
}

INSERM

\section{Source}

INSERM. (1999). Orphanet: an online rare disease and orphan drug data base. Disorder of sex development-intellectual disability syndrome. ORPHA:2983

Verloes-Gillerot-Fryns syndrome is a rare association of malformations. 